\title{
Characterization of Bombyx mori and Antheraea pernyi silk fibroins and their blends as potential biomaterials
}

\author{
Shuko Suzuki ${ }^{1}$ (D) Traian V. Chirila ${ }^{1,2,3,4,5} \cdot$ Grant A. Edwards $^{4}$
}

Received: 8 August 2016/Accepted: 17 October 2016/Published online: 27 October 2016

(c) The Author(s) 2016. This article is published with open access at Springerlink.com

\begin{abstract}
Fibroin proteins isolated from the cocoons of certain silk-producing insects have been widely investigated as biomaterials for tissue engineering applications. In this study, fibroins were isolated from cocoons of domesticated Bombyx mori (BM) and wild Antheraea pernyi (AP) silkworms following a degumming process. The object of this study was to obtain an assessment on certain properties of these fibroins in order that a concept might be had regarding the feasibility of using their blends as biomaterials. Membranes, 10-20 $\mu \mathrm{m}$ thick, which are water-insoluble, flexible and transparent, were prepared from pure fibroins and from their blends, and subjected to water vapor annealing in vacuum, with the aim of providing materials sufficiently strong for manipulation. The resulting materials were characterized by electrophoretic analysis and infrared spectrometry. The tensile properties of the membranes were measured and correlated with the results of infrared analysis. At low concentrations of any of the two fibroins, the mechanical characteristics of the membranes
\end{abstract}

Traian V. Chirila

traian.chirila@qei.org.au

1 Queensland Eye Institute, South Brisbane, QLD 4101, Australia

2 Science and Engineering Faculty, Queensland University of Technology (QUT), Brisbane, QLD 4001, Australia

3 Faculty of Medicine and Biomedical Sciences, The University of Queensland (UQ), Herston, QLD 4029, Australia

4 Australian Institute of Bioengineering and Nanotechnology (AIBN), The University of Queensland (UQ), St Lucia, QLD 4072, Australia

5 Faculty of Science, The University of Western Australia (UWA), Crawley, WA 6009, Australia appeared to be adequate for surgical manipulation, as the modulus and strength surpassed those of BM silk fibroin alone. It was noticed that high concentrations of AP silk fibroin led to a significant reduction in the elasticity of membranes.

Keywords Bombyx mori silk · Antheraea pernyi silk · Silk fibroins · Membranes · Mechanical properties · FTIR analysis

\begin{tabular}{|c|c|}
\hline \multicolumn{2}{|c|}{ Abbreviations } \\
\hline BMSF & Bombyx mori silk fibroin \\
\hline APSF & Antheraea pernyi silk fibroin \\
\hline FTIR-ATR & $\begin{array}{l}\text { Fourier transform infrared-attenuated total } \\
\text { reflectance }\end{array}$ \\
\hline MM & Molecular mass \\
\hline MMCO & Molecular-mass cut-off \\
\hline SD & Standard deviation \\
\hline SDS-PAGE & $\begin{array}{l}\text { Sodium dodecyl sulphate-polyacrylamide } \\
\text { gel electrophoresis }\end{array}$ \\
\hline
\end{tabular}

\section{Introduction}

Silks are biopolymers with a wide range of mechanical properties, which are produced by certain organisms such as insects and spiders. The silk cocoons generated in the pupation stage by the larvae of domesticated silk moth Bombyx mori (family Bombycidae) have been a source for textile fibers for millennia. Closer to our times, the two main constitutive proteins (fibroin and sericin) of the silk produced by $B$. mori silkworm and a few other silkworms of the class Insecta have been investigated also as potential biomaterials (Altman et al. 2003; Vepari and Kaplan 2007; Hakimi et al. 2007; Kundu et al. 2008; Wang et al. 2009; 
Murphy and Kaplan 2009; Harkin et al. 2011; Pritchard and Kaplan 2011; Sehnal 2011; Wenk et al. 2011; Chirila et al. 2013; Kundu et al. 2013; Hodgkinson and Bayat 2014; Khan and Tsukada 2014; Kundu et al. 2014; Patra and Engel 2014; Wang et al. 2014; Koh et al. 2015; Lamboni et al. 2015; Cao and Zhang 2016; Kapoor and Kundu 2016). This type of application implies their direct contact with the human living tissue; consequently, the ability of fibroin or sericin to function as a nontoxic substratum for the attachment and growth of cells specific to the host tissue is essential (Minoura et al. 1990, 1995a, b). B. mori silk fibroin (BMSF) has been by far the most investigated silk substratum, on which a variety of cells have been cultured in vitro successfully (Minoura et al. 1990, 1995a, b; Wang et al. 2006; Chirila et al. 2008).

In spite of generally satisfactory growth of cells reported on BMSF, the adhesion of cells to its surface appears to be rather a non-specific process, as this protein does not include any of the known recognition ligand peptide sequences for integrins (the main receptors mediating cells' anchorage to substrata). A potential strategy to enhance the cell adhesion to BMSF is to mix it with the fibroin isolated from a wild silkworm, Antheraea pernyi (family Saturniidae), henceforth APSF. The latter was shown to contain the adhesion peptide sequence arginine-glycine-aspartic acid (RGD), which is a typical ligand peptide motif for the integrin receptors on the cell surface. An earlier report showed that APSF promoted indeed a better attachment of cells than BMSF (Minoura et al. 1995a). More recent studies (Bray et al. 2013; Hogerheyde et al. 2014), involving human corneal cells, indicated acceptable cell attachment to APSF or to BMSF/APSF blends, however, an enhancement induced by APSF could not be unequivocally proved.

In this study, the pure fibroins were isolated by first removing the sericins from the silk threads, and then a range of BMSF/APSF blends were prepared, respectively, from these sericin-deprived, "regenerated" silks, and cast as membranes. The enhancement of cell adhesion to the fibroin membranes is important for tissue engineering applications, but not sufficient. Equally important is the strength of these membranes, as they will ultimately be manipulated by surgeons to be implanted. We evaluate and discuss here the characteristics of membranes made of BMSF, APSF and their blends, with an emphasis on their mechanical properties.

\section{Materials and methods}

\section{Materials}

The B. mori silkworm cocoons were provided by Tajima Shoji Co. Ltd. (Yokohama, Japan), and the A. pernyi cocoons by the Lepidoptera Breeders Association (Sleaford, UK). All chemicals were purchased from SigmaAldrich (St Louis, MO, USA). Water of high purity (Milli$\mathrm{Q}$ or equivalent quality) was used in all experiments. Minisart ${ }^{\circledR}$ filters $(0.2 \mu \mathrm{m})$ and Minisart ${ }^{\circledR}$-GF pre-filters $(0.7 \mu \mathrm{m})$ were supplied by Sartorius Stedim Biotech (Göttingen, Germany). The dialysis cassettes (Slide-ALyzer $\left.^{\circledR}\right)($ MMCO $3.5 \mathrm{kDa}$ ) were supplied by Thermo Scientific (Rockford, IL, USA), and the dialysis tubing with MMCO 12.4 kDa by Sigma-Aldrich.

\section{Preparation of regenerated fibroin solutions}

The BMSF solution was prepared according to a protocol previously reported (Chirila et al. 2008), which led to a concentration of $1.78 \% \mathrm{w} / \mathrm{v}$ BMSF (by gravimetric analysis). To obtain the APSF solution, the cocoons were dried, cut into approximately $1 \mathrm{~cm} \times 1 \mathrm{~cm}$ pieces, weighed and then placed in $1 \mathrm{~L}$ boiling solution of sodium carbonate containing $0.85 \mathrm{~g}$ of salt for $1 \mathrm{~g}$ of cocoon material. After $1 \mathrm{~h}$ of boiling, the fibrous material was squeezed to remove the excess liquid, and then treated for $20 \mathrm{~min}$, three times in succession, in $1 \mathrm{~L}$ of warm $\left(60-70{ }^{\circ} \mathrm{C}\right)$ water, followed by drying in a fume hood for at least $12 \mathrm{~h}$. The dry fibrous mass was mixed with neat calcium nitrate tetrahydrate $(20$ times excess to the amount of fibers) at $105{ }^{\circ} \mathrm{C}$ and kept for $5 \mathrm{~h}$ on an oil bath while stirring very slowly. The resulting solution was injected into pre-treated dialysis tubing (MMCO $12.4 \mathrm{kDa}$ ), which was placed into a 1-L beaker with chilled water $\left(4{ }^{\circ} \mathrm{C}\right)$ and kept in a refrigerator. Water was exchanged for fresh pre-chilled water 6 times at increasing intervals over 3 days of dialysis. The resulting fibroin solution was removed carefully from the dialysis tubing and filtered successively through $0.7-$ and $0.2-\mu \mathrm{m}$ filters into a dialysis cassette (MMCO $3.5 \mathrm{kDa}$ ) in prechilled 30\% w/v solution of poly(ethylene glycol) (MM $10 \mathrm{kDa}$ ), and left to dialyze for $\sim 10 \mathrm{~h}$. The solution collected from the dialysis cassette contained $1.50 \% \mathrm{w} / \mathrm{v}$ APSF as determined by gravimetric analysis.

\section{Preparation of fibroin membranes}

The BMSF and APSF membranes were cast from the solutions produced as described above. To make the blends, the two fibroin solutions were mixed together to provide mixtures with the following compositions (BMSF/ APSF, in \% w/w): 90/10, 70/30, 50/50, 30/70 and 10/90. Prior to casting, all solutions were allowed to homogenize in a refrigerator for $3 \mathrm{~h}$. The solutions were then poured into 45-mm glass Petri dishes, which were placed in a fandriven oven and kept for $12 \mathrm{~h}$ at $25{ }^{\circ} \mathrm{C}$. After drying, the membranes were placed in a vacuum enclosure, where they were annealed at $-80 \mathrm{kPa}$ in the presence of water (in a 
beaker) without heating. The annealing duration for the membranes rich in BMSF (70, 90 and 100\%) was $6 \mathrm{~h}$, while for the others was $24 \mathrm{~h}$. The annealing process induced complete insolubility in water.

The thickness of the dry membranes, measured with an upright stand type micrometer (US-16B, TECLOCK, Japan), was $15 \pm 5 \mu \mathrm{m}$. The membranes were transparent, insoluble in water, and displayed the characteristics of a flexible hydrogel.

\section{Gel electrophoresis analysis}

The molecular mass distribution in each of the two fibroins was investigated by sodium dodecyl sulphate-polyacrylamide gel electrophoresis (SDS-PAGE). A Novex ${ }^{\circledR}$ XCell Sure Lock ${ }^{\mathrm{TM}}$ Mini-Cell system (Life Technologies Inc, Carlsbad, CA, USA) and an EPS-250 Series II Power Supply unit (CBS Scientific Company Inc, San Diego, CA, USA) were employed. The fibroin membranes (prepared as described in the previous section) were solubilized either in a solution of lithium bromide (the BMSF membranes) at $60{ }^{\circ} \mathrm{C}$, or in neat calcium nitrate at $105{ }^{\circ} \mathrm{C}$ (the APSF and BMSF/APSF blended membranes), and the resulting solutions were dialyzed and filtered. Each solution was mixed with both $\mathrm{NuPAGE}^{\circledR}$ sample preparation reagent and NuPAGE ${ }^{\circledR}$ sample reducing agent, and heated at $70{ }^{\circ} \mathrm{C}$ for $10 \mathrm{~min}$. A volume of each solution containing about $50 \mu \mathrm{g}$ protein was loaded into a 1-mm thick 3-8\% NuPAGE $^{\circledR}$ Novex $^{\circledR}$ Tris-Acetate gel in NuPAGE ${ }^{\circledR}$ TrisAcetate SDS Running Buffer. The gels were run at a voltage of $150 \mathrm{~V}$ for $1 \mathrm{~h}$ together with a HiMark ${ }^{\mathrm{TM}}$ Prestained Protein Standard (Life Technologies). The gel was then washed in three 5-min stages with distilled water, and soaked in SimplyBlue ${ }^{\mathrm{TM}}$ SafeStain solution containing Coomassie ${ }^{\circledR}$ G-250 stain for $1 \mathrm{~h}$ under gentle stirring. The resulting gel was washed in distilled water for $1 \mathrm{~h}$ and then photographed.

\section{Mechanical testing of the membranes}

Strips $(1 \mathrm{~cm} \times 3 \mathrm{~cm})$ were cut out from each membrane and subjected to tensile measurements (for stress, modulus and elongation) in an Instron 5848 microtester (Instron, UK), equipped with a $5 \mathrm{~N}$ load cell. The gage distance was set to $14 \mathrm{~mm}$. The samples were loaded by pneumatic grips and submersed in phosphate buffer solution (pre-heated to $37 \pm 3{ }^{\circ} \mathrm{C}$ ) in a BioPuls ${ }^{\mathrm{TM}}$ unit for 5 min prior to stretching. Stress-strain plots were generated during the measurements, and the Young's moduli were computed in the linear region. Elongation at break was also measured. The mean values were calculated from results generated by six measurements for each membrane, which were cut out from at least three different membranes for the same composition. The results were processed by the one-way analysis of variance (ANOVA) in conjunction with TukeyKramer multiple comparisons test using the GraphPad InStat ${ }^{\circledR}$ Version 3.10.

\section{Analysis by Fourier transform infrared-attenuated total reflectance (FTIR-ATR) spectrometry}

The FTIR-ATR spectra were recorded in a Nicolet Nexus ${ }^{\circledR}$ 5700 FTIR spectrometer (Thermo Electron Corp., Marietta, $\mathrm{OH}$, USA) equipped with a diamond ATR accessory and the OMNIC 7 software package. Each spectrum resulted by the co-addition of 64 scans in the range $4000-525 \mathrm{~cm}^{-1}$ at a resolution of $8 \mathrm{~cm}^{-1}$.

\section{Results and discussion}

While the literature dedicated to mechanical properties of BMSF is extensive, the APSF has been considerably less investigated. A survey of the relevant literature on APSF showed that structure, thermal properties, spectrometric characteristics and crystallization patterns were the topics of main interest, rather than its mechanical properties. The latter have been reported in only one article ( $\mathrm{Fu}$ et al. 2011), and restricted to the native AP fibers extracted from mature larvae's glands. Although the regenerated APSF has been also prepared and studied (Kweon et al. 2000; Zuo et al. 2009), its mechanical properties were not assessed. Structurally, APSF appeared to be closer to the fibroin produced by spiders (spidroin) than to BMSF. In fact, studies on BMSF/APSF films cast either from fibroins collected from the larvae's glands (Tsukada et al. 1994) or from regenerated fibroins (Wu et al. 2012) have suggested some physical incompatibility between these two proteins due to crystalline phase separation, but no mechanical evaluation was carried out to corroborate this observation.

We are developing in our laboratories silk fibroin membranes as substrata for growing ocular cells (corneal or retinal) to create fibroin-cells constructs to be used in the treatment of blinding conditions caused by trauma or disease (Chirila et al. 2008, 2016; Harkin et al. 2011; Madden et al. 2011; Shadforth et al. 2016). The successful use of implants made of silk fibroins is critically related to the tensile stress applied during surgical manipulation. There is a large body of evidence, including our experimental results, that BMSF as such has mechanical properties superior to almost all other biopolymers proposed or used as biomaterials. Considering the absence of reports on mechanical characteristics of membranes made from BMSF/APSF blends, we have carried out such measurements in this study. An illustrative stress-strain plot is 
shown in Fig. 1, and the results of complete mechanical evaluation for all samples are given in Table 1.

Comparing BMSF and APSF as such, the latter membranes were stiffer and stronger. In their blends, we noticed a decrease in both modulus and ultimate strength in the region of equal concentrations of the two components, while they increase in the regions of either low BMSF or low APSF. This is consistent with the observation (Tsukada et al. 1994) that in BMSF/APSF blends the crystalline compatibility is high at low concentrations (about $20 \%$ w/w or less) of either component, but crystalline phase separation occurs when their concentrations are similar (e.g. in the range $40-60 \% \mathrm{w} / \mathrm{w}$ of any of these components). It is believed ( $\mathrm{Hu}$ et al. 2011) that an enhanced crystallinity in silk fibroins leads to enhanced rigidity and strength, therefore, a reduced crystallinity due to phase separation could cause lower modulus and tensile strength. Our results appear to confirm the above assumptions.

There was a dramatic reduction of the elongation at break (Table 1) as the proportion of APSF in blends increased, an obvious consequence of the enhanced

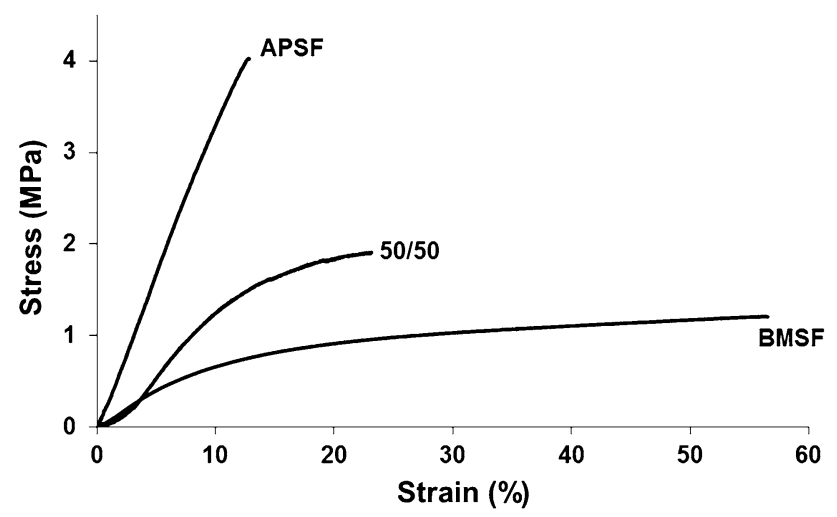

Fig. 1 Stress-strain plots for BMSF, APSF and their equivalent blend (50:50 by weight) stiffness of this component (its modulus is about 3 times higher than that of BMSF).

Electrophoretic mobility of the polypeptide components in each fibroin was investigated by SDS-PAGE with an aim to reveal the distribution of their molecular masses. The analysis showed (Fig. 2) typical smear patterns for BMSF, APSF and their blend, such indicating that the original polypeptides were degraded during degumming due to hydrolytic reactions at the elevated temperatures and $\mathrm{pH}$ values employed in the process. It is known that in these conditions BMSF can be extensively degraded (Trefilleti et al. 1980; Zuo et al. 2006), and this can be assumed for APSF too. Our analysis clearly showed (Fig. 2) that the hydrothermal degradation of APSF was more advanced than that of BMSF, likely due to higher temperatures involved in the processing of the former. This, in turn, may

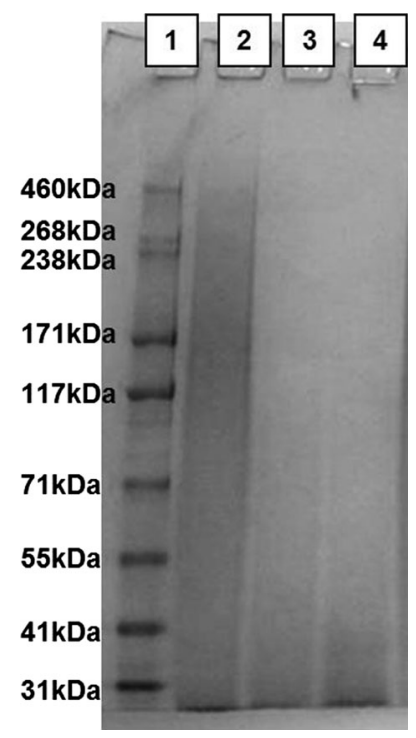

Fig. 2 Electrophoretic patterns of BMSF, APSF, and their equivalent blend: 1 molar mass marker positions; 2 BMSF; 3 blend BMSF/APSF $50 / 50 \% \mathrm{w} / \mathrm{w} ; 4$ APSF. (See text for details of analysis)
Table 1 Tensile characteristics of membranes made of BMSF, APSF and their blends (mean $\pm \mathrm{SD}, n=6)$

\begin{tabular}{llll}
\hline $\begin{array}{l}\text { Composition BMSF/APSF }(\% \\
\text { w/w) }\end{array}$ & $\begin{array}{l}\text { Young's modulus } \\
(\mathrm{MPa})\end{array}$ & $\begin{array}{l}\text { Ultimate strength } \\
(\mathrm{MPa})\end{array}$ & $\begin{array}{l}\text { Elongation at break } \\
(\%)\end{array}$ \\
\hline $100 / 0$ & $12.9 \pm 3.5^{\mathrm{a}}$ & $1.7 \pm 0.6$ & $58.0 \pm 22.3$ \\
$90 / 10$ & $17.2 \pm 2.0^{\mathrm{a}}$ & $2.0 \pm 0.4$ & $51.7 \pm 16.7$ \\
$70 / 30$ & $17.7 \pm 2.3^{\mathrm{a}}$ & $2.1 \pm 0.3$ & $43.7 \pm 14.4$ \\
$50 / 50$ & $15.4 \pm 6.5^{\mathrm{a}}$ & $1.4 \pm 0.4^{\mathrm{b}}$ & $28.8 \pm 9.4$ \\
$30 / 70$ & $22.8 \pm 6.9$ & $2.3 \pm 1.2$ & $19.7 \pm 9.7$ \\
$10 / 90$ & $32.2 \pm 6.1$ & $2.7 \pm 0.7$ & $15.3 \pm 2.3$ \\
$0 / 100$ & $36.4 \pm 8.8$ & $3.2 \pm 1.9$ & $14.3 \pm 7.4$ \\
\hline
\end{tabular}

${ }^{a}$ These values are statistically different $(p<0.001)$ from those measured for the membranes containing 90 and $100 \%$ w/w APSF

b This value is statistically different $(p<0.05)$ from that measured for $100 \%$ w/w APSF 


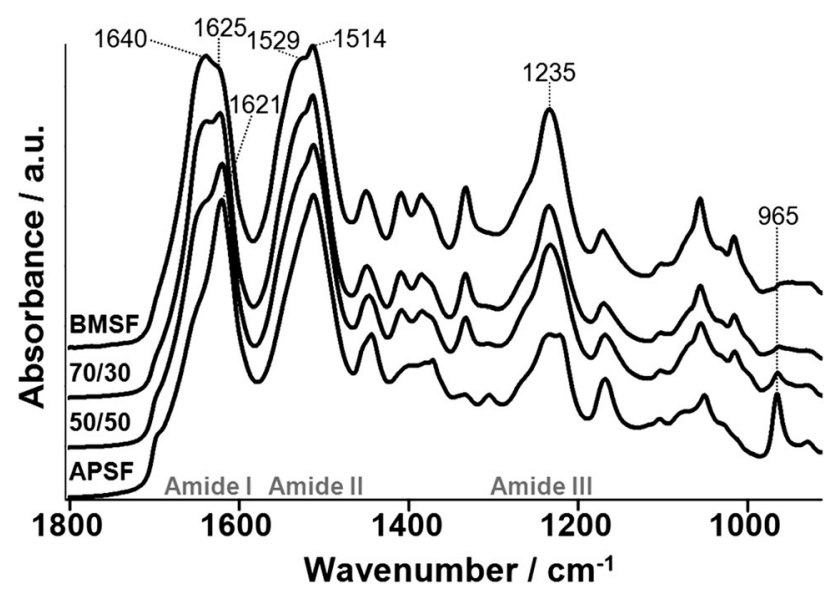

Fig. 3 The FTIR-ATR spectra of BMSF, APSF and two of their blends $(70 / 30$ and $50 / 50 \% \mathrm{w} / \mathrm{w})$

contribute to the significant decrease in elongation and increase in stiffness of the blends with high content of APSF.

The membranes were also analyzed by FTIR-ATR spectrometry with an aim to gain some insight regarding the relation between mechanical properties and the secondary structure of the silk proteins. Figure 3 shows the spectra of BMSF, APSF and their blends in the respective proportions of 70/30 and 50/50\% w/w. BMSF displayed strong absorption bands in the Amide I $\left(1640 \mathrm{~cm}^{-1}\right)$, Amide II $\left(1529 \mathrm{~cm}^{-1}\right)$, and Amide III $\left(1235 \mathrm{~cm}^{-1}\right)$ regions, which are commonly attributed to random coil conformation in the amorphous regions of the protein, and also at 1625 and $1514 \mathrm{~cm}^{-1}$ corresponding to $\beta$-sheet structures in the crystalline region (Magoshi and Magoshi 1977; Tsukada et al. 1994; Lu et al. 2011). Comparatively, in the spectrum of APSF, the strong absorption bands at 1621, 1514 and $1235 \mathrm{~cm}^{-1}$ indicated a higher $\beta$-sheet content, which is supported by an absorption at $965 \mathrm{~cm}^{-1}$ attributable also to $\beta$-sheet structures (Kweon et al. 2000; Li et al. 2003). The spectra of blends showed bands characteristic to the two fibroins, with the band intensities corresponding to the BMSF/APSF ratios, and no additional absorption bands. This finding is in agreement with a previous study (Tsukada et al. 1994), where it was interpreted as a result of very weak, or even absent, molecular interactions between the two fibroins. This may be, indeed, related to the quantitative decline in the mechanical properties when none of the two fibroins is predominant in the blend.

\section{Conclusions}

The membranes made of blends of BMSF and APSF display adequate mechanical strength and stiffness when any of the two components is quantitatively predominant in the formulation. However, when the proportions of BMSF and APSF are similar, the strength and modulus are lower due to possible crystalline phase separation in this region. This aspect, and also the decrease in their elasticity induced by increasing the amount of APSF, shall be considered when selecting the most appropriate formulation for a membrane that will have to be surgically manipulated during tissue engineering applications.

Authors' contributions TVC: designed and coordinated the study; wrote the manuscript; contributed to the interpretation of results. SS: carried out the production and analysis of silk fibroins; drafted sections of the manuscript; executed and organized the graphic material in the manuscript; reviewed the final draft. GAE: contributed to mechanical analysis of fibroins and to interpretation of results; reviewed the final draft.

Acknowledgments This work was supported by the Queensland Eye Institute Foundation, Queensland, Australia, through the Viertel's Vision program.

\section{Compliances with ethical standards}

Conflict of interest The authors declare that there is no conflict of interest of a scientific or commercial nature. The authors have no relevant affiliations or financial support from any organization that might have a financial interest in the subject matter.

Open Access This article is distributed under the terms of the Creative Commons Attribution 4.0 International License (http://crea tivecommons.org/licenses/by/4.0/), which permits unrestricted use, distribution, and reproduction in any medium, provided you give appropriate credit to the original author(s) and the source, provide a link to the Creative Commons license, and indicate if changes were made.

\section{References}

Altman GH, Diaz F, Jakuba C, Calabro T, Horan RL, Chen J, Lu H, Richmond J, Kaplan DL (2003) Silk-based biomaterials. Biomaterials 24:401-416

Bray LJ, Suzuki S, Harkin DG, Chirila TV (2013) Incorporation of exogenous RGD peptide and inter-species blending as strategies for enhancing human corneal limbal epithelial cell growth on Bombyx mori silk fibroin membranes. J Funct Biomater $4: 74-88$

Cao T-T, Zhang Y-Q (2016) Processing and characterization of silk sericin from Bombyx mori and its application in biomaterials and biomedicines. Mater Sci Eng C 61:940-952

Chirila TV, Barnard Z, Zainuddin Harkin DG, Schwab IR, Hirst LW (2008) Bombyx mori silk fibroin membranes as potential substrata for epithelial constructs used in the management of ocular surface disorders. Tissue Eng A 14:1203-1211

Chirila TV, Suzuki S, Bray LJ, Barnett NL, Harkin DG (2013) Evaluation of silk sericin as a biomaterial: in vitro growth of human corneal limbal epithelial cells on Bombyx mori sericin membranes. Prog Biomater 2:14. doi:10.1186/2194-0517-2-14

Chirila TV, Suzuki S, Hirst LW, Harkin DG (2016) Reconstruction of the ocular surface using biomaterial templates. In: Chirila TV, 
Harkin DG (eds) Biomaterials and regenerative medicine in ophthalmology, 2nd edn. Elsevier, Amsterdam, pp 179-218

Fu C, Porter D, Chen X, Vollrath F, Shao Z (2011) Understanding the mechanical properties of Antheraea pernyi silk-from primary structure to condensed structure of the protein. Adv Funct Mater 21:729-737

Hakimi O, Knight DP, Vollrath F, Vadgama P (2007) Spider and mulberry silkworm silks as compatible biomaterials. Compos B 38:324-337

Harkin DG, George KA, Madden PW, Schwab IR, Hutmacher DW, Chirila TV (2011) Silk fibroin in ocular tissue reconstruction. Biomaterials 32:2445-2458

Hodgkinson AT, Bayat A (2014) Silk for dermal tissue engineering. In: Kundu SC (ed) Silk biomaterials for tissue engineering and regenerative medicine. Elsevier, Amsterdam, pp 456-471

Hogerheyde TA, Suzuki S, Stephenson SA, Richardson NA, Chirila TV, Harkin DG, Bray LJ (2014) Assessment of freestanding membranes prepared from Antheraea pernyi silk fibroin as a potential vehicle for corneal epithelial cell transplantation. Biomed Mater 9:025016

Hu X, Shmelev K, Sun L, Gil E-S, Park S-H, Cebe P, Kaplan DL (2011) Regulation of silk material structure by temperaturecontrolled water vapour annealing. Biomacromolecules 12:1686-1696

Kapoor S, Kundu SC (2016) Silk protein-based hydrogels: promising advanced materials for biomedical applications. Acta Biomater 31:17-32

Khan MMR, Tsukada M (2014) Electrospun silk sericin nanofibers for biomedical applications. In: Kundu SC (ed) Silk biomaterials for tissue engineering and regenerative medicine. Elsevier, Amsterdam, pp 125-156

Koh L-D, Cheng Y, Teng C-P, Khin Y-W, Loh X-J, Tee S-Y, Low M, Ye E, Yu H-D, Zhang Y-W, Han M-Y (2015) Structures, mechanical properties and applications of silk fibroin materials. Prog Polym Sci 46:86-110

Kundu SC, Dash BC, Dash R, Kaplan DL (2008) Natural protective glue protein, sericin bioengineered by silkworms: potential for biomedical and biotechnological applications. Prog Polym Sci 33:998-1012

Kundu B, Rajkhowa R, Kundu SC, Wang X (2013) Silk fibroin biomaterials for tissue regenerations. Adv Drug Deliv Rev 65:457-470

Kundu B, Kurland NE, Bano S, Patra C, Engel FB, Yadavalli VK, Kundu SC (2014) Silk proteins for biomedical applications: bioengineering perspectives. Prog Polym Sci 39:251-267

Kweon HY, Um IC, Park YH (2000) Thermal behaviour of regenerated Antheraea pernyi silk fibroin film treated with aqueous methanol. Polymer 41:7361-7367

Lamboni L, Gauthier M, Yang G, Wang Q (2015) Silk sericin: a versatile material for tissue engineering and drug delivery. Biotechnol Adv 33:1855-1867

Li M, Tao W, Kuga S, Nishiyama Y (2003) Controlling molecular conformation of regenerated wild silk fibroin by aqueous ethanol treatment. Polym Adv Technol 14:694-698

Lu Q, Zhang B, Li M, Zuo B, Kaplan DL, Huang Y, Zhu H (2011) Degradation mechanism and control of silk fibroin. Biomacromolecules 12:1080-1086

Madden PW, Lai JNX, George KA, Giovenco T, Harkin DG, Chirila TV (2011) Human corneal endothelial cell growth on a silk fibroin membrane. Biomaterials 32:4076-4084
Magoshi J, Magoshi Y (1977) Physical properties and structure of silk. V. Thermal behaviour of silk fibroin in the random-coil conformation. J Polym Sci Polym Phys Ed 15:1675-1683

Minoura N, Tsukada M, Nagura M (1990) Physico-chemical properties of silk fibroin membrane as a biomaterial. Biomaterials 11:430-434

Minoura N, Aiba S, Higuchi M, Gotoh Y, Tsukada M, Imai Y (1995a) Attachment and growth of fibroblast cells on silk fibroin. Biochem Biophys Res Commun 208:511-516

Minoura N, Aiba S, Gotoh Y, Tsukada M, Imai Y (1995b) Attachment and growth of cultured fibroblast cells on silk protein matrices. J Biomed Mater Res 29:1215-1221

Murphy AR, Kaplan DL (2009) Biomedical applications of chemically-modified silk fibroin. J Mater Chem 19:6443-6450

Patra C, Engel FB (2014) Silk for cardiac tissue engineering. In: Kundu SC (ed) Silk biomaterials for tissue engineering and regenerative medicine. Elsevier, Amsterdam, pp 429-455

Pritchard EM, Kaplan DL (2011) Silk fibroin biomaterials for controlled release drug delivery. Expert Opin Drug Deliv $8: 797-811$

Sehnal F (2011) Biotechnologies based on silk. In: Vilcinskas A (ed) Insect biotechnology. Gorb SN (ed) Biologically-inspired systems series, vol 2. Springer, Dordrecht, pp 211-224

Shadforth AMA, Chirila TV, Harkin DG, Kwan ASL, Chen FK (2016) Biomaterial templates for the culture and transplantation of retinal pigment epithelial cells: a critical review. In: Chirila TV, Harkin DG (eds) Biomaterials and regenerative medicine in ophthalmology, 2nd edn. Elsevier, Amsterdam, pp 263-289

Trefilleti V, Conio G, Pioli F, Cavazza B, Perico A, Patrone E (1980) The spinning of silk, 1: molecular weight, subunit structure, and molecular shape of Bombyx mori fibroin. Makromol Chem 181:1159-1179

Tsukada M, Freddi G, Kasai N (1994) Physical properties and phase separation structure of Antheraea pernyi/Bombyx mori silk fibroin blend films. J Polym Sci B Polym Phys 32:1175-1182

Vepari C, Kaplan DL (2007) Silk as a biomaterial. Prog Polym Sci 32:991-1007

Wang Y, Kim H-J, Vunjak-Novakovic G, Kaplan DL (2006) Stem cell-based tissue engineering with silk biomaterials. Biomaterials 27:6064-6082

Wang X, Cebe P, Kaplan DL (2009) Silk proteins - biomaterials and engineering. In: Lutz S, Bornscheuer UT (eds) Protein engineering handbook. Wiley-VCH, Weinheim, pp 939-959

Wang Z, Zhang Y, Zhang J, Huang L, Liu J, Li Y, Zhang G, Kundu SC, Wang L (2014) Exploring natural silk protein sericin for regenerative medicine: an injectable, photoluminescent, celladhesive 3D hydrogel. Sci Rep 4:7064. doi:10.1038/srep07064

Wenk E, Merkle HP, Meinel L (2011) Silk fibroin as a vehicle for drug delivery applications. J Control Rel 150:128-141

Wu X, Jiao Y, Liu G, Yan S, Li M (2012) Structure of Antheraea pernyi/Bombyx mori silk fibroin scaffolds. Adv Mater Res 535-537:2321-2325

Zuo B, Dai L, Wu Z (2006) Analysis of structure and properties of biodegradable regenerated silk fibroin fibers. J Mater Sci 41:3357-3361

Zuo B, Liu L, Zhang F (2009) Structure and properties of regenerated Antheraea pernyi silk fibroin filaments. J Appl Polym Sci 113:2160-2165 